\title{
Implantation of bFGF-treated islet progenitor cells ameliorates streptozotocin-induced diabetes in rats
}

\author{
Ge LI ${ }^{1, \#}$, Li-song HUANG ${ }^{2, \#, ~ M i n g-h o n g ~ J I A N G ~}{ }^{1}$, Hui-ling $\mathrm{WU}^{1}$, Jing $\mathrm{CHEN}^{1}$, Yin HUANG ${ }^{1}$, Yan SHEN ${ }^{1}$, SaiYin HE-XI-GE ${ }^{1}$, \\ Wei-wei Fan ${ }^{1}$, Zhi-qiang $\mathrm{LU}^{3, *}$, Da-ru LU ${ }^{1, *}$ \\ ${ }^{1}$ Key Laboratory of Genetic Engineering, Fudan-VARI Genetic Epidemiology Center and MOE Key Laboratory of Contemporary Anthro- \\ pology, School of Life Sciences, Fudan University, Shanghai 200433, China; ${ }^{2}$ Emergency Department of Navy General Hospital, Beijing \\ 100037, China; ${ }^{3}$ Department of Endocrinology and Metabolism of Zhongshan Hospital, Fudan University, Shanghai 200032, China
}

Aim: To examine whether implantation of islet preparation-derived proliferating islet cells (PIC) could ameliorate diabetes in rats. Methods: PIC were expanded from rat islet preparation by supplementation of basic fibroblast growth factor (bFGF) and implanted into rats with streptozotocin (STZ)-induced diabetes through the portal vein. Body weight and blood glucose levels were measured. Serum insulin levels were measured by radioimmunoassay. The presence of insulin-positive cells was determined by hematoxylin and immunohistochemical staining.

Results: Cultured islet cells $(\mathrm{CIC})$ were demonstrated to dedifferentiate in vitro, and the apoptosis ratios reached more than $50 \%$ by the 15th day post-isolation. PIC cells treated with bFGF $(20 \mathrm{ng} / \mathrm{mL})$ continued growing within 30 days after isolation, and no apoptotic cells were detected. Implantation of PIC into diabetic rats was capable of ameliorating diabetes, in terms of the restoration of euglycemia, weight gain, improved glucose response and elevated serum insulin levels for up to 130 days. Livers derived from PIC-implanted rats were examined for insulin expression and single insulin-positive cells. In addition, most islets of PIC-implanted STZ-induced diabetic rats were intact at 130 days post-transplantation and comparable to those of normal rats.

Conclusion: Implantation of bFGF-treated proliferating islet cells is a promising cellular therapeutic approach for diabetes.

Keywords: diabetes; cellular therapy; islet transplantation; islet cell culture; islet progenitor cells

Acta Pharmacologica Sinica (2010) 31: 1454-1463; doi: 10.1038/aps.2010.130; published online18 Oct 2010

\section{Introduction}

Islet transplantation is one of the most promising therapies for type 1 diabetes. Compared with the injection of exogenous insulin, islet transplantation provides relatively long-term restoration of euglycemia and dynamic insulin secretion in response to glucose level ${ }^{[1-3]}$. Clinical application of islet transplantation is severely hampered by a scarcity of islet donors. To overcome the shortage of tissue donors, one strategy is to generate a large number of $\beta$ cells or $\beta$ cell-like insulin-producing cells for replacement therapy. It is believed that islet regeneration plays an important role in maintaining islet mass in adult animals ${ }^{[4,5]}$ and humans ${ }^{[6]}$. Earlier results supported the idea that neogenerated islets were derived from differentiated progenitor cells, which might be located in ducts ${ }^{[4,7]}$,

\footnotetext{
" Ge LI and Li-song HUANG contributed equally to this work.

* To whom correspondence should be addressed.

E-mail drlufd@gmail.com (Da-ru LU); zhqlu@it.com.cn (Zhi-qiang LU)

Received 2010-03-11 Accepted 2010-05-27
}

acinar tissues ${ }^{[8,9]}$, islets ${ }^{[10]}$, or multi-tissues ${ }^{[8,11]}$. Recent studies have demonstrated that $\beta$ cell replication was the primary source of postnatal neogeneration of $\beta$ cells $^{[12,13]}$.

Despite the unclear nature of islet generation, these results suggest the possibility that functional islet or islet-like cells could be expanded from pancreatic tissues. Isolation and in vitro differentiation of islet progenitor cells have been reported by many groups ${ }^{[1,2]}$. The isolation strategies included clonal identification ${ }^{[14]}$, flow-cytometric cell sorting ${ }^{[15]}$, and selective cultivation $^{[5,16-19]}$. Another report demonstrated that combination treatment with epidermal growth factor and gastrin could increase functional $\beta$ cell mass in vitro ${ }^{[20]}$. A common feature of these studies was that the combination of growth factors with other reagents activated the outgrowth of progenitor cells or mature $\beta$ cells, whereas withdrawal of growth factor induced differentiation toward the endocrine phenotype. However, most of these reports did not evaluate the implantation of in vitro-generated insulin-producing cells with regard to their ability to ameliorate diabetes. To our knowledge, it has not been determined whether proliferating cells that have lost the 
ability to differentiate could indirectly induce endocrine differentiation and reverse hyperglycemia.

On the other hand, in vivo islet regeneration promises another path to diabetes therapy. Insulinotropic hormones, such as betacellulin ${ }^{[21]}$, glucagon-like peptide $1^{[22]}$, and insulinlike growth factor $1^{[23]}$, have been used to facilitate islet regeneration. Other investigators have reported that transplanted bone marrow could initiate islet regeneration ${ }^{[24]}$ in pancreas, suggesting that islet regeneration could also be facilitated by implanted cells.

In this study, we sought to establish a simple method to expand cells from rat islet preparation in vitro and to ameliorate STZ-induced diabetes through implantation of these proliferating cells.

\section{Materials and methods}

Animals

Outbred male Sprague-Dawley rats were purchased from the Shanghai Laboratory Animal Center (Chinese Academy of Sciences, Shanghai, China) and maintained in specific pathogenfree conditions. Animals were provided with rodent chow and tap water ad libitum on a 12-hour light/dark cycle. All animal experimentation in the study was conducted in accord with accepted standards of humane animal care.

\section{Rat Islet Isolation and Culture}

Pancreas islets were isolated from the pancreas of the outbred male Sprague-Dawley rats (250 to $300 \mathrm{~g}$ body weight) using a collagenase digestion technique and discontinuous Ficoll density gradient centrifugation as described previously ${ }^{[25]}$. The pancreas was distended via intraductal injection of collagenase P solution (Roche, Basel, Switzerland) into the common bile duct after occlusion of the distal end, close to the duodenum. Digestion was performed in a water bath at $37^{\circ} \mathrm{C}$ for approximately 40 minutes. The digestion was then stopped by the addition of ice-cold Hank's balanced salt solution (HBSS) supplemented with 5\% FBS. The suspension was washed twice to remove collagenase (HBSS, $250 \times g, 3 \mathrm{~min}, 4^{\circ} \mathrm{C}$ ). The acinar cells and islets were separated by Ficoll density gradient centrifugation. The islet-rich layer was collected and washed with HBSS, and islet purity was assessed by dithizone staining.

Islet preparation cells with $70 \%-80 \%$ purity of pancreatic islet cells were cultured in RPMI-1640 medium with 15\% fetal bovine serum $(v / v), 100 \mu \mathrm{g} / \mathrm{mL}$ penicillin, and $100 \mathrm{mg} / \mathrm{mL}$ streptomycin, then incubated at $37{ }^{\circ} \mathrm{C}$ under humidified conditions with $5 \% \mathrm{CO}_{2}$. To facilitate the growth of islet preparation cells, recombinant rat bFGF $(20 \mathrm{ng} / \mathrm{mL}$ ) (R\&D Systems, Minneapolis, MN, USA) was supplemented.

\section{RT-PCR}

Total cell RNA was extracted following the manufacturer's protocol, using TRIzol reagent (Invitrogen, Carlsbad, CA, USA), and cDNA synthesis was performed following the manufacturer's protocol, using ReverTra Ace (TOYOBO, Tokyo, Japan). PCR was carried out in a $20-\mu \mathrm{L}$ reaction volume using $1 \mu \mathrm{L}$ of the diluted cDNA solution (normalized correspond- ing to the density of $\beta$-actin PCR product after 25 PCR cycles) as template, mixed with $10 \mu \mathrm{L}$ of PCR Master Mix (Tiangen, Beijing, China), $10 \mathrm{pmol}$ of each primer, and $7 \mu \mathrm{L}$ deionized water.

The forward and reverse primers of each PCR set were designed to be located in different exon(s), based on sequences obtained from GenBank. The gene name and the sequences of the primers, sizes of PCR products, cycles, and annealing temperature for each pair are listed in Table 1.

\section{Cell cycle analysis by propidium iodide $(\mathrm{PI})$ staining}

Cells were harvested and fixed with $70 \%$ ice-cold ethanol overnight at $-20{ }^{\circ} \mathrm{C}$; treated with $0.1 \mathrm{mg} / \mathrm{mL}$ RNase A (Roche, Basel, Switzerland) and $0.05 \%$ Triton X-100 in PBS solution at $37^{\circ} \mathrm{C}$ for $40 \mathrm{~min}$, incubated with $50 \mu \mathrm{g} / \mathrm{mL}$ PI (Sigma, St Louis, MO, USA) in PBS solution at room temperature for 30 min, suspended in PBS and submitted for FACS analysis.

\section{Apoptosis analysis}

Cell apoptosis was analyzed by the TdT-mediated dUTP NickEnd Labeling (TUNEL) method, using the DeadEnd ${ }^{\mathrm{TM}}$ Fluorimetric TUNEL System (Promega, WI, USA). Sample preparation was carried out following the manufacturer's protocol for FACS analysis.

\section{Induction of diabetes and islet transplantation}

Outbred Sprague-Dawley rats, 250-300 g, were rendered diabetic by intra-abdominal cavity injection of $60 \mathrm{mg} / \mathrm{kg}$ of STZ (Sigma, St Louis, MO, USA) that was freshly dissolved in citrate buffer ( $\mathrm{pH}$ 4.5). Diabetes was confirmed by blood glucose levels greater than $300 \mathrm{mg} / \mathrm{dL}$ prior to surgery. Then 5 to $9 \times 10^{6}$ PIC or CIC cells, suspended in 0.8 to $0.9 \mathrm{~mL}$ of PBS, were injected into the portal vein, which was exposed with an abdominal incision. After islets were infused, bleeding was stopped by the application of pressure. At $1600 \mathrm{~h}$, body weight and blood glucose levels were measured, the latter with a portable glucose meter (Medisense; Bedford, MA, USA). Measurements were performed every three days during the first month and once a week thereafter. Glucose levels less than $200 \mathrm{mg} / \mathrm{dL}$ were considered euglycemic. Redevelopment of diabetes was considered when 2 consecutive nonfasting glucose levels were greater than $300 \mathrm{mg} / \mathrm{dL}$.

\section{Radioimmunoassay (RIA)}

$1 \mathrm{~mL}$ of blood per rat was collected from the fossa orbitalis vein. Serum insulin contents were determined by RIA following the manufacturer's protocol, using a rat insulin RIA kit (Union, Tianjin, China).

\section{Immunohistochemical staining}

Specimens were fixed in $4 \%$ buffered paraformaldehyde solution and embedded in paraffin after dehydration. To detect the presence of insulin-positive cells, histological analysis was performed by hematoxylin and immunohistochemical staining. Sections $4 \mu \mathrm{m}$ thick were deparaffinized after washing and blocking, then incubated with rabbit anti-rat insulin 
Table 1. Primers of $\beta$-actin, insulin, glucagon, somatostatin, Pdx1, amylase, nestin, and C-myc.

\begin{tabular}{|c|c|c|c|c|}
\hline Gene name & & Primer & Product size (bp) & $\begin{array}{l}\text { GeneBank }^{\mathrm{TM}} \\
\text { accession № }\end{array}$ \\
\hline Insulin & $\begin{array}{l}\text { Forwards } \\
\text { Reverse }\end{array}$ & $\begin{array}{l}\text { 5' TCT TCT ACA CAC CCA TGT CCC } 3^{\prime} \\
5^{\prime} \text { GGT GCA GCA CTG ATC CAC } 3^{\prime}\end{array}$ & 148 & J00747-8 \\
\hline Glucagon & $\begin{array}{l}\text { Forwards } \\
\text { Reverse }\end{array}$ & $\begin{array}{l}5^{\prime} \text { TGA TGA ACA CCA AGA GGA ACC } 3^{\prime} \\
5^{\prime} \text { CCT TTC ACC AGC CAA GCA ATG } 3^{\prime}\end{array}$ & 145 & J00786-90 \\
\hline Somatostatin & $\begin{array}{l}\text { Forwards } \\
\text { Reverse }\end{array}$ & $\begin{array}{l}\text { 5' CCA GAC TCC GTC AGT TTC TGC 3' } \\
\text { 5' CTC AGG CTC CAG GGC ATC GTT 3' }\end{array}$ & 128 & K02808 \\
\hline Amylase & $\begin{array}{l}\text { Forwards } \\
\text { Reverse }\end{array}$ & $\begin{array}{l}5^{\prime} \text { AGG AAC ATG GTT GCC TTC AG } 3^{\prime} \\
5^{\prime} \text { AAT GAC ATC ACA GTA TGT GCC } 3^{\prime}\end{array}$ & 186 & M24962 \\
\hline Nestin & $\begin{array}{l}\text { Forwards } \\
\text { Reverse }\end{array}$ & $\begin{array}{l}\text { 5' GAG TCC CTG AGG TCT CCA GAA G 3' } \\
5^{\prime} \text { CTC TCA AGC ATC TGG TCC TCT G } 3^{\prime}\end{array}$ & 141 & NM_012987 \\
\hline C-myc & $\begin{array}{l}\text { Forwards } \\
\text { Reverse }\end{array}$ & $\begin{array}{l}5^{\prime} \text { CGC CTA CAT CCT GTC CGT TC } 3^{\prime} \\
5^{\prime} \text { TCC AGC TCC TCC TCA CTT CC } 3^{\prime}\end{array}$ & 148 & Y00396 \\
\hline
\end{tabular}

monoclonal antibody (Santa Cruz, CA, USA) at $4{ }^{\circ} \mathrm{C}$ overnight. Anti-rabbit HRP antibody (Antibody Diagnostica Inc., Stamford, CA, USA) was applied and incubated for $30 \mathrm{~min}$ at room temperature. Finally, the specimens were colored with substrate 3,3-diaminobenzidine solution and counterstained with hematoxylin.

Cellular immunofluorescence was carried out using similar methods. Cells were mounted on $0.1 \%$ poly-lysine covered coverslips, fixed with $4 \%$ PFA, treated with $0.05 \%$ Triton X-100 to penetrate the cell membrane, and then blocked with $3 \%$ BSA. The sections were incubated with primary antibodies at $4{ }^{\circ} \mathrm{C}$ overnight, washed three times in PBS, incubated with secondary antibodies for $30 \mathrm{~min}$ to $2 \mathrm{~h}$ at room temperature, washed 3 times in PBS, stained with DAPI, and then examined under the fluorescence microscope. All primary antibodies were monoclonal and purchased from Santa Cruz Biotechnology (Santa Cruz, CA, USA), except for cytokeratin antibody, which was purchased from Sigma (St Louis, MO, USA) and binds to several types of cytokeratin. All secondary antibodies were purchased from Chemicon (USA).

\section{Results}

bFGF stimulated vigorous proliferation of rat islet preparationderived cells

First, islets of $70 \%-80 \%$ purity (Figure 1A) were obtained from rats and cultured as described in "Materials and Methods." Cell clumps disappeared and cells became homomorphous within 5 days, regardless of whether bFGF was supplemented. There was no significant difference in growth rate between the two groups within 5 days (data not shown). The growth rate of regularly cultured islet preparation cells gradually slowed and finally stopped at about 15 days post-isolation (data not shown). In contrast, cells treated with bFGF continued growing, with an average doubling time of less than $24 \mathrm{~h}$ for at least 30 days after isolation (data not shown). In this study, the proliferating cells derived from islet preparation cells by addition of bFGF were denoted as proliferating islet cells (PIC) (Figure $1 B)$; cultured islet preparation cells under regular conditions were denoted as cultured islet cells (CIC) (Figure 1C).

\section{Gradual loss of differentiation in PIC and CIC}

To examine the gene expression of PIC and CIC, RT-PCR was performed on RNA samples prepared from FIC: CIC on days 10 and 20 and PIC on days 10, 20, and 40 post-isolation.

As illustrated in Figure 1D, expression of endocrine hormones - insulin, glucagon, somatostatin, and transcription factor pancreatic duodenal homeobox-1 (Pdx1) - decreased gradually in both groups. Endocrine function was partially preserved within 20 days of culture. Supplementation with bFGF accelerated the loss of endocrine function, which might be a side effect of its proliferation-promoting effects. On the other hand, levels of exocrine enzymes such as amylase diminished quite quickly in vitro.

Expression levels of nestin and c-myc were also examined 

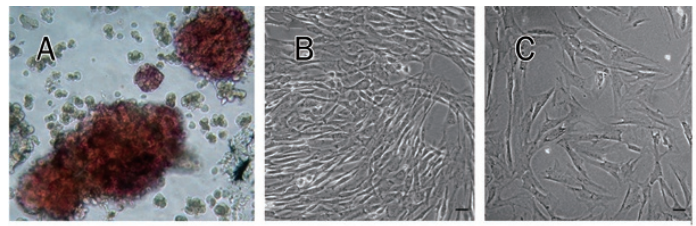

D
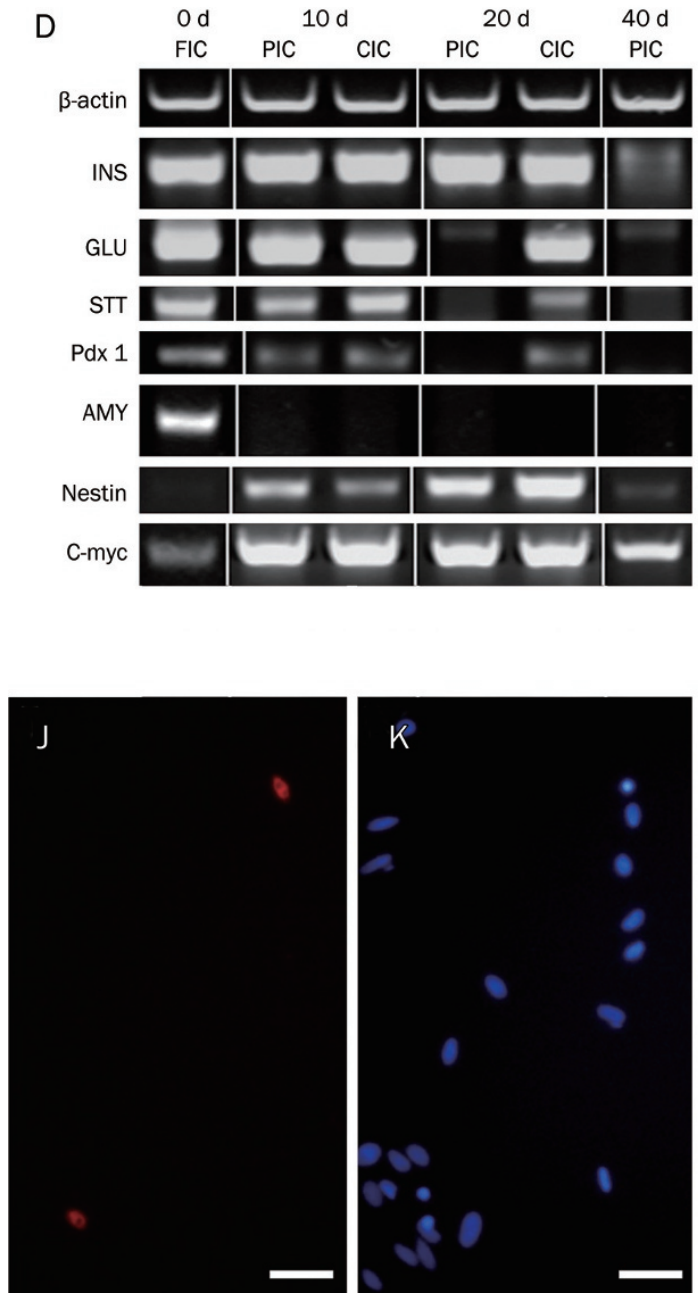
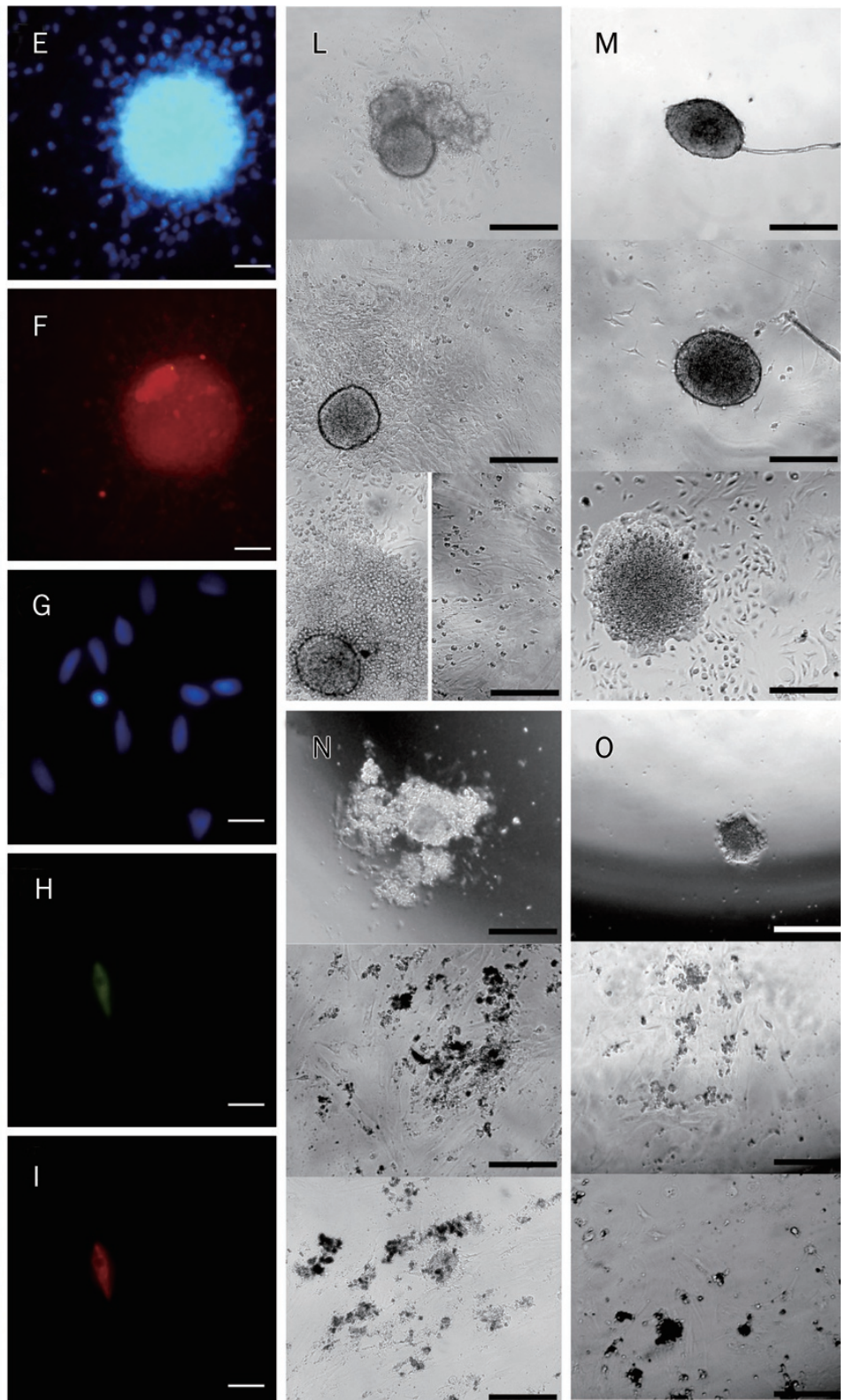

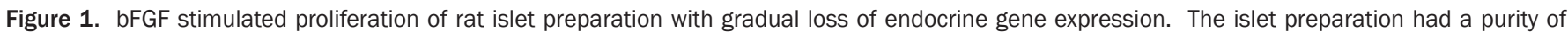

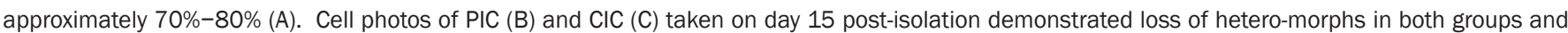

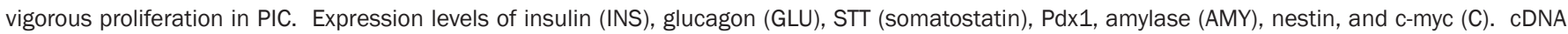

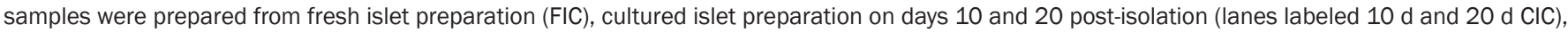

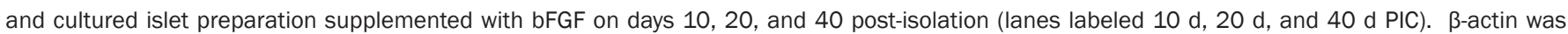

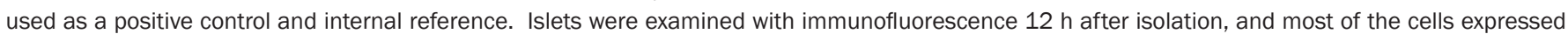

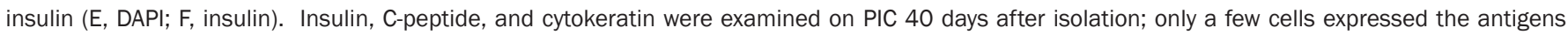

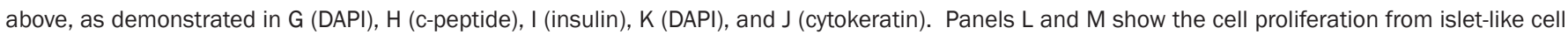

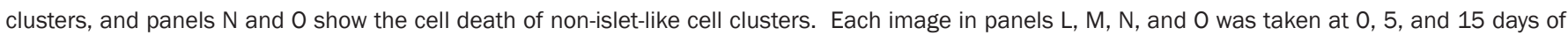
culture (from top to bottom). Scale bar: $1 \mu \mathrm{m}$ for B, C, G, H, I; $2 \mu \mathrm{m}$ for J, K; $5 \mu \mathrm{m}$ for E, F; and 2 mm for L, M, N, and O.

owing to previous reports that nestin ${ }^{[19,26,27]}$ was a possible molecular marker of islet progenitor cells and that c-myc plays an important role in beta cell replication ${ }^{[28]}$, hypertrophy and loss of differentiation in vivo ${ }^{[29]}$. In our experiments, there were no obvious differences in the expression patterns of either nestin or c-myc when cells treated with bFGF were compared with those that were not. Remarkably, increasing expression levels of both genes have been observed in both groups (Figure 1D).

Furthermore, immunofluorescence confirmed the results of RT-PCR. Although most cells were insulin-positive immediately after isolation (Figure $1 \mathrm{E}$ and $1 \mathrm{~F}$ ), only a few 

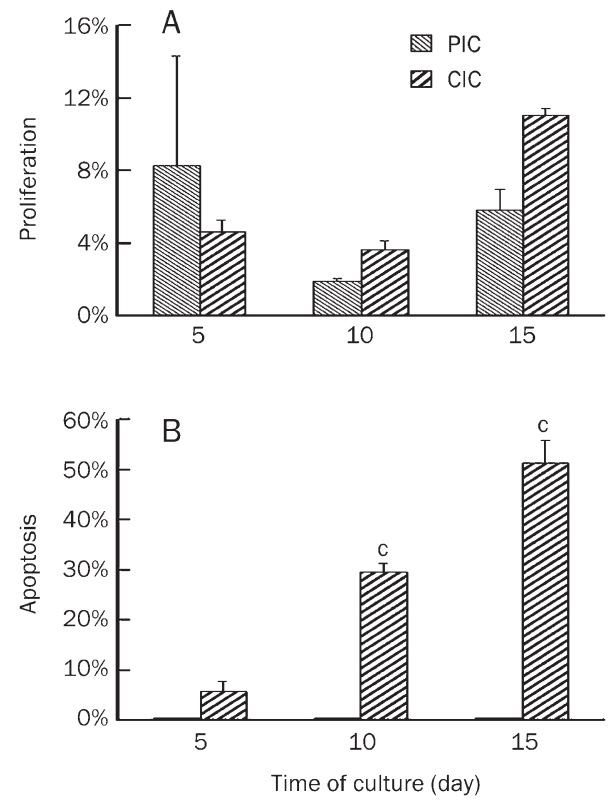

Figure 2. bFGF protected cultured islet preparation cells from apoptosis and had no significant effect on dividing capability. S-phase (A) and apoptosis (B) ratios were determined using FACS on PIC and CIC samples on days 5,10 , and 15 post-isolation (light-shaded downward diagonal columns: PIC; heavy-shaded upward diagonal columns: $\mathrm{CIC}$ ). There was no significant difference in S-phase ratio between $\mathrm{PIC}$ and $\mathrm{CIC}$ groups at any time point or between any of the two time points within one group $(P>0.05)$. The apoptosis ratio of $\mathrm{CIC}$ samples on days 10 and 15 were significantly higher than those of other samples $\left({ }^{\circ} P<0.01\right)$. All values were reported as mean \pm SEM. Significant difference was determined as $P<0.05$ using one-way ANOVA post hoc tests (LSD test, no significant difference within groups).

IPPCs expressed insulin or C-peptide after 40 days of culture (Figure 1G, 1H, and 1I). No Pdx1- or Ngn3-positive cells were detected at day 40 post-isolation among PIC. On the other hand, some authors have reported that cytokeratin 19 was expressed in in vitro cultured islet cells ${ }^{[5]}$. In this study, cytokeratin was expressed by only a few day-40 IPPCs but not generally expressed by most of the cells (Figure 1J and 1K).

Proliferating cells came from islet or islet-peripheral cells but not islet-unrelated cells

To determine the source of the proliferating cells, original islet preparation cells were diluted and cultured in 96-well plates. In total, 98 wells were cultured, and 42 of them contained only one cell cluster; some of these were islet-like.According to observations over 15 days, cell proliferation was observed only in the wells containing islet-like cell clusters (Figure 1L and $1 \mathrm{M})$. In the case of the wells containing non-islet-like cell clusters, no cell growth was observed, and almost all cells died within 10 days (Figure $1 \mathrm{~N}$ and 1O). No evidence of cell proliferation derived from a single cell was observed during cultivation.

Additionally, cells that were on the bottom layer during the islet isolation process, which should be mostly acinar cells, were cultured in the same condition, and no cell proliferation was observed.

bFGF facilitates the proliferation of islet preparation cells by reducing the apoptosis ratio rather than inducing cell replication Cell cycles were first examined in CIC and PIC samples from days 5,10 , and 15 post-isolation, and the percentages of cells in S-phase were determined. Surprisingly, there was no significant difference between PIC and CIC at any time point or between any two time points within the CIC or PIC group. Additionally, the S-phase ratio of CIC reached more than 10\% by day 15 post-isolation, when growth stopped (Figure 2A).

To clarify the mechanism of the proliferation-facilitation effects of bFGF on islet preparation cells, cell apoptosis ratios were further determined using TUNEL-FACS. The proportion of apoptotic cells in PIC samples was less than 1\%; in the case of CIC samples, it was significantly higher at both time points and also increased significantly during in vitro culture, reaching more than $50 \%$ by day 15 post-isolation (Figure $2 \mathrm{~B}$ ).

Taking these findings together, we conclude that the vigorous proliferation of PIC was due mainly to bFGF-mediated protection against apoptosis.

\section{Transplanted PIC reversed hyperglycemia in STZ-induced diabetic} rats

PIC at day 15 post-isolation were harvested for implantation into STZ-induced diabetic rats through the portal vein $(n=9)$. Two other groups were implanted with 15-day CIC $(n=4)$ or PBS $(n=4)$ as sham surgery. A group treated with STZ and without surgery served as the control group $(n=4)$. STZtreated rats with blood glucose levels between 300 and 600 $\mathrm{mg} / \mathrm{dL}$ were used in this study.

As indicated in Figure 3A, the PIC group demonstrated significantly lower blood glucose levels $(P<0.01)$ than those in the other 3 groups throughout the entire post-surgery period and achieved restoration of euglycemia $(<200 \mathrm{mg} / \mathrm{dL})$. CIC implantation also had little effect on blood glucose levels, which were significantly lower than those in the sham surgery and control groups at day 12 but returned to hyperglycemic levels within one month post-surgery.

Two cases in the PIC group developed hyperglycemia again, observed on days 25 and 160, respectively. No auto-recovery was observed in the sham surgery or control group in this study.

When comparing the blood glucose levels in the sham surgery and control groups, no significant difference was observed throughout the experimental period.

\section{Body weight increased in both the PIC and CIC transplantation groups}

The body weights of the PIC-implanted, CIC-implanted, sham surgery, and STZ control rats were also monitored, yielding similar results (Figure 3B). The PIC-implanted rats weighed significantly more than the rats in the sham surgery and control groups. The body weights of CIC-implanted rats were neither significantly lower than those of the PIC group nor 

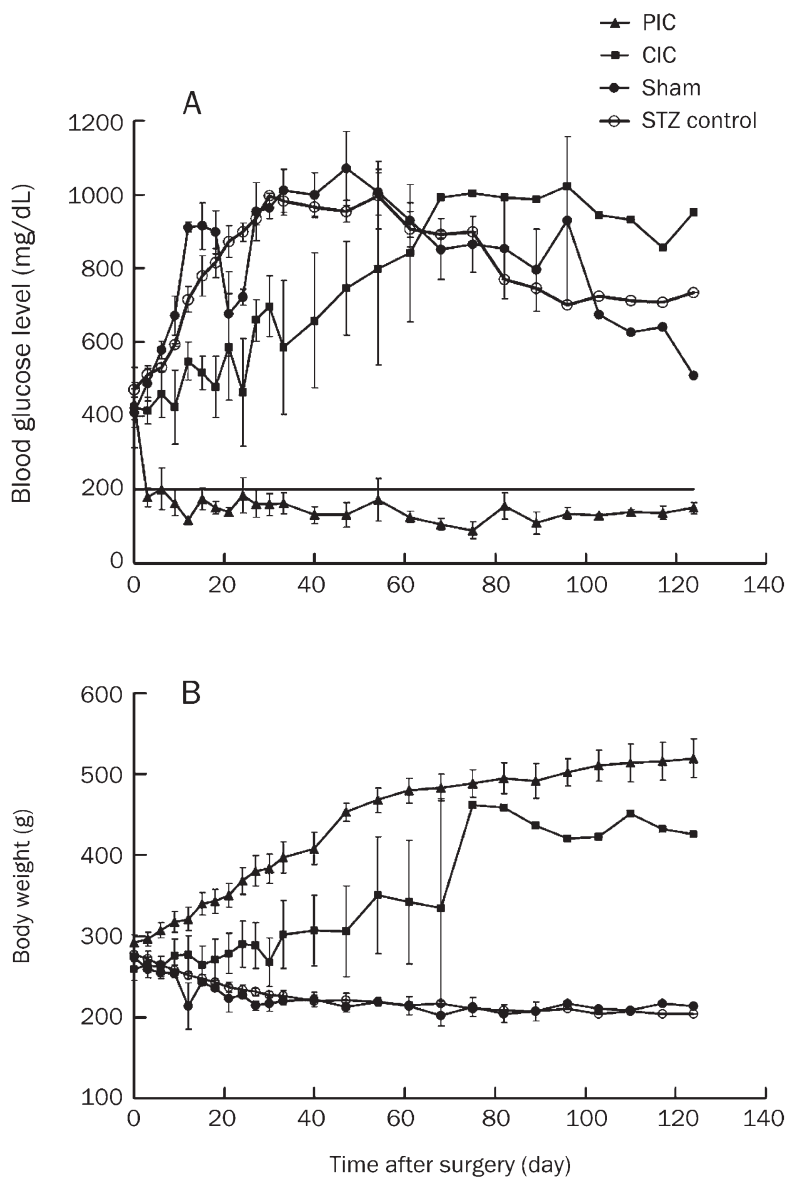

Figure 3. PIC implantation ameliorated STZ-induced diabetes. Blood glucose levels and body weights of diabetic rats that underwent PIC implantation (triangle, $n=9$ ), CIC implantation (square, $n=4$ ), sham surgery (circle, $n=4$ ) with STZ treatment, as well as the control group without surgery (open circle, $n=4$ ), are shown in $A$ and $B$, respectively. With respect to blood glucose levels, PIC group values were significantly lower than those for all other groups at all time points $(P<0.01)$; CIC group values were significantly lower than those for the sham surgery and control groups only at some time points from days 12 to 30 post-isolation $(P<0.05)(A)$. With respect to body weight, values in the PIC group were higher than in the sham surgery and control groups at almost all time points $(P<0.01)$. The $\mathrm{CIC}$ group differed only slightly from the PIC group, the sham surgery group and the control group $(P>0.05)(B)$. There was no difference between the sham surgery and control groups in either case. All values were reported as mean \pm SEM, and significant difference was determined as $P<0.05$ using an independent samples $t$-test, with equal variances assumed.

significantly higher than those of the sham surgery or control groups.

Similar to the trend in blood glucose levels, there were no significant differences between the sham surgery and control groups, which indicated that surgery has little effect on blood glucose level or body weight in STZ-treated rats.

\section{Delayed glucose response in PIC-implanted rats}

To further evaluate the function of implanted cells, intraperito- neal glucose tolerance testing (IPGTT) on PIC transplantation $(n=5)$, diabetic control $(n=3)$, and normal rats $(n=3)$ was performed on day 30 post-surgery. As illustrated in Figure 4A, remarkable improvement of glucose tolerance was achieved in PIC-implanted rats as compared with diabetic control rats. However, as compared with the blood glucose levels in normal rats (which peaked at 15 min post-glucose injection and returned to baseline within $120 \mathrm{~min}$ ), a moderate delay of glucose response was observed in PIC-implanted rats. In the latter group, the glucose response peaked at 15-90 min and returned to baseline at $180 \mathrm{~min}$.

\section{Serum insulin levels were improved by PIC implantation}

Serum was collected on days 10 and 40 post-surgery from PICimplanted $(n=6)$, CIC-implanted $(n=6)$, sham surgery $(n=6)$, and normal rats $(n=6)$ for determination of nonfasting serum insulin levels. Insulin levels in PIC-implanted rats were comparable to those of normal rats $(P>0.05)$ on day 10 but not day 40 , and were significantly higher than those of CIC-implanted or sham surgery rats at both time points (Figure 4B). Such data implied the restoration of serum insulin levels by PIC implantation and gradual loss of graft function despite longlasting euglycemia. Additionally, the difference in insulin levels between the two time points was not significant in the PIC group but was significant in the CIC group (Figure 4B), suggesting that graft function was lost more slowly in the case of PIC implantation.

\section{Single insulin-positive cells were detected in the livers of PIC- implanted rats}

Livers derived from PIC-implanted rats on days 4 and 34 posttransplantation were examined for insulin expression. Single insulin-positive cells could be easily recognized in liver sections at 4 days after transplantation (Figure 5A), indicating the contribution of ectopic insulin expression in liver to the correction of hyperglycemia. In the case of post-transplantation rats on day 34, although their blood glucose levels remained below $200 \mathrm{mg} / \mathrm{dL}$, no insulin-positive cells were detected (Figure 5B). Notably, insulin-positive cells were detected in STZtreated mice ${ }^{[30]}$. In our study, no insulin-positive cells were observed in STZ-induced diabetic rats (Figure 5C), indicating that the insulin-positive cells in liver derive, either directly or indirectly, from implanted PIC.

\section{Islet mass was maintained in pancreata of PIC-implanted rats}

To elucidate the causes of long-term correction of hyperglycemia in PIC-implanted rats, we examined pancreatic islets of PIC-implanted rats 130 days after surgery, with a diabetic rat 130 days after sham surgery and a normal rat of similar age as controls. Nearly all islets in diabetic control rats were destroyed; hardly any intact islets could be observed (Figure $5 \mathrm{G})$. By contrast, our examination of more than 20 pancreas sections derived from two PIC-implanted rats determined that most islets were intact (Figure 5E and 5F) and comparable to those of normal rats (Figure 5D). Additionally, the rat that re-developed diabetes on day 106 post-transplantation was 


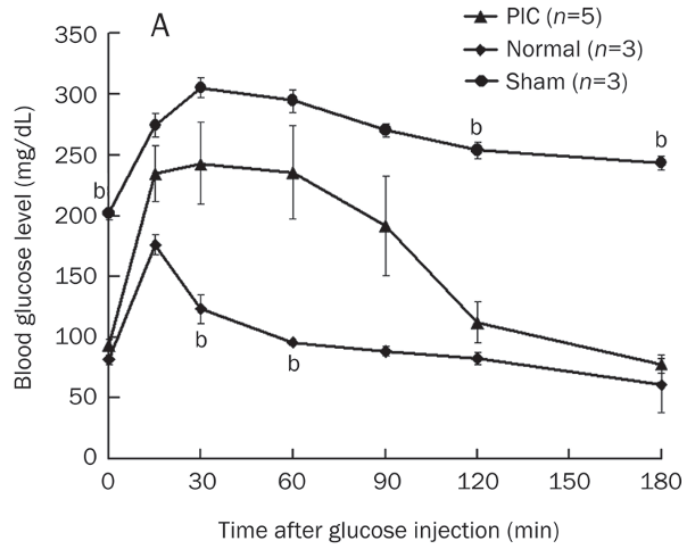

$10 \mathrm{~d}$ post-surgery ( $n=6 /$ group $)$ 70 40 d post-surgery ( $n=6 /$ group)

B Normal $(n=6)$

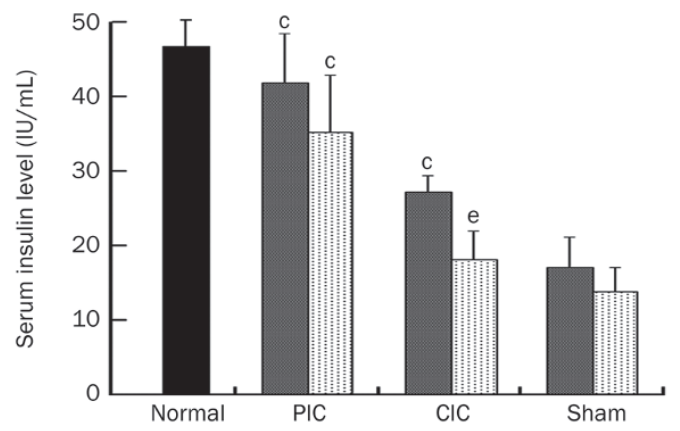

Figure 4. PIC-implanted rats demonstrated improved tolerance in response to glucose challenge (A) and elevated levels of serum insulin (B). IPGTT was performed on day 30 post-surgery in rats that had received PIC that same day (triangle, $n=5$ ), sham surgery rats (circle, $n=3$ ), and normal rats (diamond, $n=3$ ). Delayed but significantly improved glucose response was observed in PIC-implanted rats. Blood glucose levels in normal rats were significantly lower than those in sham group rats at all time points (not indicated). Blood glucose levels in PIC-implanted rats were significantly lower than those in the sham group at 0,120 , and $180 \mathrm{~min}\left({ }^{\mathrm{b}} \mathrm{P}<0.05\right)$ and significantly higher than those in normal rats at 30 and 60 min $\left({ }^{b} P<0.05\right)$ after glucose injection. Serum insulin levels were determined in rats that received PIC implantation, rats that received $\mathrm{CIC}$ implantation, rats that underwent sham surgery on day 10 post-surgery (gray columns) and rats that underwent sham surgery on day 40 post-surgery (dotted columns), with normal rats (black column) as control. Sample size in each group was 6 . The only insulin levels comparable to those of normal control animals $(P>0.05)$ were those of PIC-implanted rats on day 10 post-surgery (not shown). PIC-implanted rats on days 10 and 40 post-isolation and CICimplanted rats on day 10 post-isolation demonstrated significantly higher insulin levels than sham rats $\left({ }^{\circ} P<0.01\right)$. The difference in insulin levels between two time points within one group was significant only in the $\mathrm{CIC}$ implantation group $\left({ }^{\mathrm{e}} \mathrm{P}<0.05\right)$. Additionally, insulin levels in PIC-implanted rats were significantly higher than those in $\mathrm{CIC}$-implanted rats at both time points (not shown). All values were reported as mean \pm SEM, and significant difference was determined as $P<0.05$ using one-way ANOVA post hoc tests (LSD test, no significant difference within groups).

examined to determine islet mass, and modest destruction of the islet was observed (Figure $5 \mathrm{H}$ ).
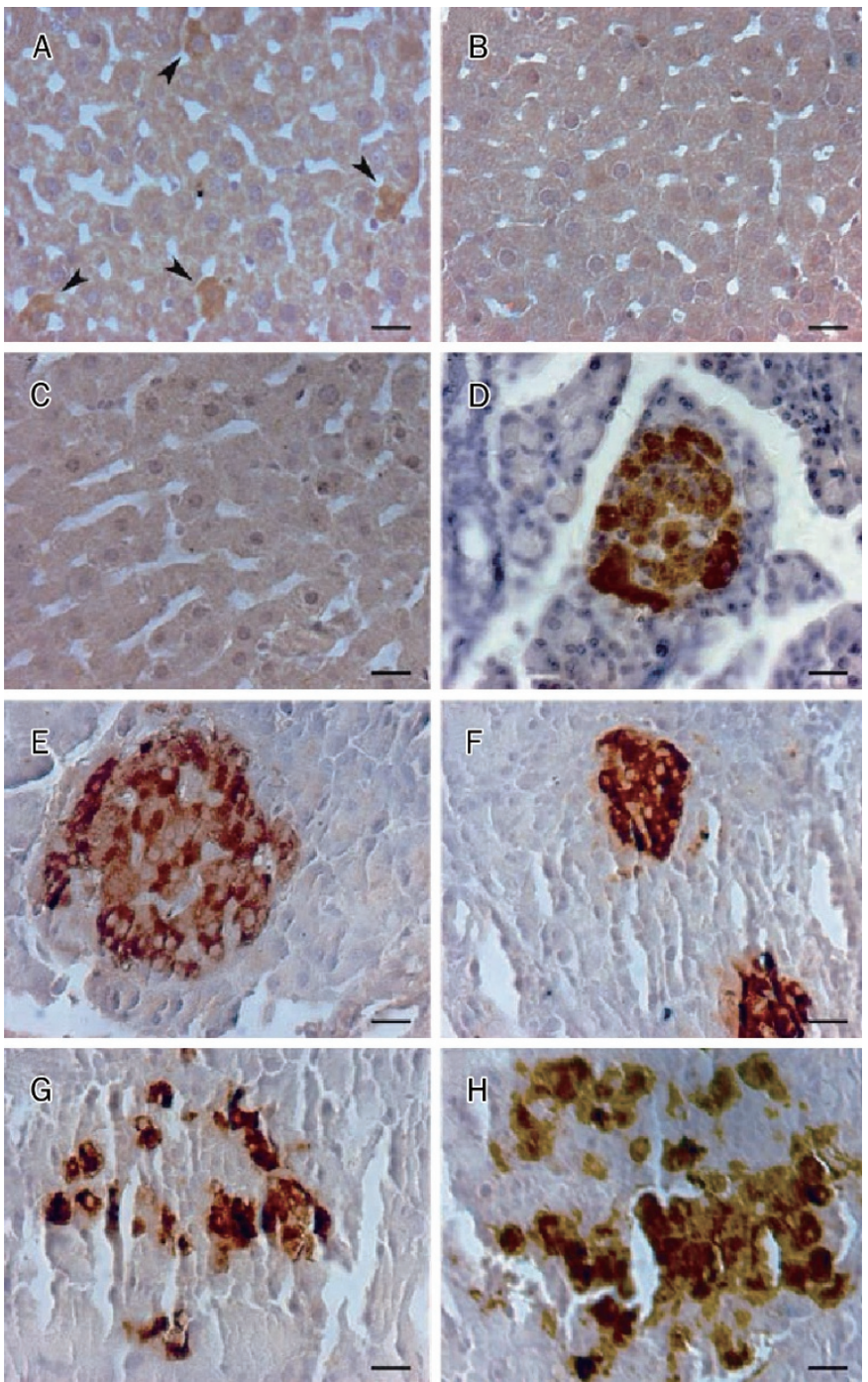

Figure 5. Insulin IHC examination. Single insulin-positive cells could be easily recognized in the liver sections of PIC-implanted rats on day 4 posttransplantation ( $\mathrm{A}$, indicated by arrowhead). No insulin-positive cells were observed in PIC-implanted rats on day 34 post-isolation (B) or in diabetic control rats 10 days after STZ injection (C). Islets of PIC-implanted rats at day 130 post-isolation (E, F) remained intact and comparable to those of normal rats of similar age (D). Serious islet destruction was observed in diabetic control rats at day 130 post-surgery $(G)$. Modest islet destruction was observed in the pancreata of rats that re-developed diabetes $(H)$. Scale bar $=2 \mu \mathrm{m}$.

\section{Discussion}

According to the in vitro characterization of PIC and CIC, nestin and c-myc were both upregulated shortly after isolation in both groups. These data suggested the replication of either islet progenitor cells or $\beta$ cells during in vitro culture. Additionally, the cessation of growth observed in cultured islet preparation cells was caused mainly by apoptosis rather than decreased cell replication. Supplementation with bFGF efficiently protected cultured cells from apoptosis, which should enhance the proliferation of islet preparation cells. Others 
also reported an increase of cytokeratin 19-positive cells in the population of in vitro cultured islet preparation cells and identified ductal cells as the primary source of proliferating cells ${ }^{[5]}$. In this study, using immunofluorescence examination, we recognized only a few cytokeratin-positive cells in PIC samples, without strong expression in the other types of cells. According to previous reports, it is possible that these cells might redifferentiate into islet cells under suitable conditions.

Despite the various strategies for in vitro re-establishment of pancreatic islets, re-differentiation of islet cells after expansion is still a challenge in need of a solution ${ }^{[31]}$. There are several reports that amelioration of diabetes was achieved by implantation of in vitro-generated insulin-producing cells ${ }^{[16,32-35]}$. In our experiments, exocrine cells accounted for only a small proportion of the total cultured cells, as determined by real-time PCR. Actually, when the acinar cells were cultured using the same protocol, massive cell death was observed within days, with no evidence of cell proliferation.

According to single-cluster culture experiments, the proliferating cells, termed PIC in this study, should derive from islet cells, or at least islet-related cells. Single islets were observed to proliferate during cultivation. Also, it could not be excluded that some cells other than islet cells, such as certain peripheral cells surrounding the islets, contributed to proliferation. After all, no evidence of cell proliferation was observed in non-islet-like cell clusters. Single cells were not observed to proliferate, suggesting that such proliferation might require contributions from different types of cells.

It has also been reported that partial trans-differentiated hepatocytes committed full endocrine differentiation in vivo when transplanted into diabetic mice ${ }^{[36]}$, and putative islet progenitor cells differentiated to endocrine and acinar lineage cells when implanted into pancreas ${ }^{[15]}$. These reports indicated that the in vivo environment of diabetic recipients could facilitate differentiation toward the endocrine lineage. Under the hypothesis that dedifferentiated proliferating cells might commit endocrine differentiation when implanted into diabetic subjects, in this study PIC were directly implanted into diabetic rats to ameliorate diabetes.

With this strategy, the initial blood glucose level might induce the failure of euglycemia restoration. In this study, however, 16 diabetic rats received PIC implantation, and hyperglycemia was reversed in only 9 of them. When initial blood glucose levels were compared, it turned out that all the rats with blood glucose levels lower than $600 \mathrm{mg} / \mathrm{dL}$ achieved euglycemia after PIC implantation, whereas rats with blood glucose levels higher than $600 \mathrm{mg} / \mathrm{dL}$ failed to achieve euglycemia (data not shown). It is well known that high glucose levels could induce apoptosis of $\beta$ cells as well as jeopardize islet transplantation, which might explain the failure to restore euglycemia in recipients with an initial blood glucose level higher than $600 \mathrm{mg} / \mathrm{dL}$. Rats with initial blood glucose levels higher than $600 \mathrm{mg} / \mathrm{dL}$ might also be more vulnerable to diabetes. Notably, the rats in this study were were outbred, not inbred.

By contrast, in the case of IPGTT, the delay in PIC suggested that the implanted PIC were not equivalent to natural islets. It is possible that newly promoted insulin-producing cells were not functionally comparable to the original beta cells, especially in terms of insulin secretion. This phenomenon of the delay of IPGTT in PIC also suggested that the reversal of high blood glucose levels by PIC implantation did not merely reflect regeneration of native islets. Further studies are needed to clarify the reasons for the delayed IPGTT response.

Because of the difficulty in simulating differentiation of stem cells in vitro, some groups have tried to implant stem cells directly into patients and then allowed them to differentiate in vivo. This approach is frequently used to implant bone marrow mesenchymal cells for injury healing, a technique that has already been applied in clinical trials ${ }^{[37]}$. Further research will be necessary to determine whether putative islet progenitor cells can ameliorate diabetes when implanted. However, it has been reported that when bone marrow-derived cells were transplanted into diabetic mice, these cells were able to transdifferentiate into insulin-producing cells ${ }^{[38]}$ and were also able to initiate islet regeneration ${ }^{[24]}$. In addition, bone marrowderived mesenchymal stem cells promoted islet revascularization when co-cultured in vitro ${ }^{[39]}$ and improved islet function when co-implanted ${ }^{[40]}$. In this study, the cultured islets displayed mesenchymal-like morphology during in vitro culture. It is possible that the cells, proliferating under stimulation of bFGF and, furthermore, able to reverse hyperglycemia, were not islet cells themselves but rather peri-islet cells. In the future, peri-islet and islet cells should be isolated and studied separately to determine which cell type(s) respond(s) to bFGF and contribute to the amelioration of diabetes.

In this study, single insulin-positive cells, but not wellformed islets, were observed in the livers of PIC recipients. Further examination revealed that long-term restoration of euglycemia is probably associated with islet regeneration or protection of islets from destruction. This hypothesis was supported not only by the comparable islet mass of PIC-implanted rats that remained euglycemic at the time of examination but also by the islet destruction observed in PIC-implanted rats that re-developed diabetes. To elucidate the mechanism by which implanted PIC ameliorate diabetes, further investigation should be carried out; a lineage-tracing strategy should be quite helpful.

In summary, the current study reported that proliferating and dedifferentiated cells derived from islet preparations were able to ameliorate diabetes without undergoing in vitro redifferentiation, providing a novel strategy for cellular therapy to treat diabetes.

\section{Acknowledgements}

We thank Dr Yong-xiang LI for demonstrating the islet isolation surgery and the technique for portal vein transplantation. We also thank Dr Hui GENG for critical review of the manuscript.

\section{Author contribution}

Da-ru LU and Zhi-qiang LU designed the experimental pro- 
gram; Ge LI and Li-song HUANG performed research; Minghong JIANG, Hui-ling WU, Jing CHEN, Yin HUANG, and SaiYin HE-XI-GE contributed analytical reagents and tools; Yan SHEN and Wei-wei FAN analyzed data; Ge LI wrote the paper.

\section{Abbreviation}

bFGF: basic fibroblast growth factor, HBSS: Hanks' balanced salt solution, IPGTT: intraperitoneal glucose tolerance testing, CIC: cultured islet cells, PIC: proliferating islet cells, Pdx1: pancreatic duodenal homeobox-1, STZ: streptozotocin.

\section{References}

1 Bonner-Weir S, Weir GC. New sources of pancreatic beta-cells. Nat Biotechnol 2005; 23: 857-61.

2 Jun HS, Yoon JW. Approaches for the cure of type 1 diabetes by cellular and gene therapy. Curr Gene Ther 2005; 5: 249-62.

3 Sharma A, Zangen DH, Reitz P, Taneja M, Lissauer ME, Miller CP, et al. The homeodomain protein IDX-1 increases after an early burst of proliferation during pancreatic regeneration. Diabetes 1999; 48: 507-13.

4 Gu D, Sarvetnick N. Epithelial cell proliferation and islet neogenesis in IFN-g transgenic mice. Development 1993; 118: 33-46.

5 Bonner-Weir S, Taneja M, Weir GC, Tatarkiewicz K, Song KH, Sharma A, et al. In vitro cultivation of human islets from expanded ductal tissue. Proc Natl Acad Sci USA 2000; 97: 7999-8004.

6 Meier JJ, Lin JC, Butler AE, Galasso R, Martinez DS, Butler PC. Direct evidence of attempted beta cell regeneration in an 89-year-old patient with recent-onset type 1 diabetes. Diabetologia 2006; 49: 1838-44.

7 Bonner-Weir S, Baxter LA, Schuppin GT, Smith FE. A second pathway for regeneration of adult exocrine and endocrine pancreas. A possible recapitulation of embryonic development. Diabetes 1993; 42: 171520.

8 Wang GS, Rosenberg L, Scott FW. Tubular complexes as a source for islet neogenesis in the pancreas of diabetes-prone BB rats. Lab Invest 2005; 85: 675-88.

9 Lipsett M, Finegood DT. beta-cell neogenesis during prolonged hyperglycemia in rats. Diabetes 2002; 51: 1834-41.

10 Guz Y, Nasir I, Teitelman G. Regeneration of pancreatic beta cells from intra-islet precursor cells in an experimental model of diabetes. Endocrinology 2001; 142: 4956-68.

11 Fernandes A, King LC, Guz Y, Stein R, Wright CV, Teitelman G. Differentiation of new insulin-producing cells is induced by injury in adult pancreatic islets. Endocrinology 1997; 138: 1750-62.

12 Dor Y, Brown J, Martinez OI, Melton DA. Adult pancreatic beta-cells are formed by self-duplication rather than stem-cell differentiation. Nature 2004; 429: 41-6.

13 Georgia S, Bhushan A. Beta cell replication is the primary mechanism for maintaining postnatal beta cell mass. J Clin Invest 2004; 114: 963-8.

14 Seaberg RM, Smukler SR, Kieffer TJ, Enikolopov G, Asghar Z, Wheeler $\mathrm{MB}$, et al. Clonal identification of multipotent precursors from adult mouse pancreas that generate neural and pancreatic lineages. Nat Biotechnol 2004; 22: 1115-24.

15 Suzuki A, Nakauchi $\mathrm{H}$, Taniguchi $\mathrm{H}$. Prospective isolation of multipotent pancreatic progenitors using flow-cytometric cell sorting. Diabetes 2004; 53: 2143-52.

16 Ramiya VK, Maraist M, Arfors KE, Schatz DA, Peck AB, Cornelius JG. Reversal of insulin-dependent diabetes using islets generated in vitro from pancreatic stem cells. Nat Med 2000; 6: 278-82.
17 Gershengorn MC, Hardikar AA, Wei C, Geras-Raaka E, MarcusSamuels B, Raaka BM. Epithelial-to-mesenchymal transition generates proliferative human islet precursor cells. Science 2004; 306 : 2261-4.

18 Choi Y, Ta M, Atouf F, Lumelsky N. Adult pancreas generates multipotent stem cells and pancreatic and nonpancreatic progeny. Stem Cells 2004; 22: 1070-84.

19 Zulewski H, Abraham EJ, Gerlach MJ, Daniel PB, Moritz W, Muller B, et al. Multipotential nestin-positive stem cells isolated from adult pancreatic islets differentiate ex vivo into pancreatic endocrine, exocrine, and hepatic phenotypes. Diabetes 2001; 50: 521-33.

20 Suarez-Pinzon WL, Lakey JR, Brand SJ, Rabinovitch A. Combination therapy with epidermal growth factor and gastrin induces neogenesis of human islet \{beta\}-cells from pancreatic duct cells and an increase in functional \{beta\}-cell mass. J Clin Endocrinol Metab 2005; 90: 3401-9.

21 Li L, Yi Z, Seno M, Kojima I. Activin A and betacellulin: effect on regeneration of pancreatic beta-cells in neonatal streptozotocintreated rats. Diabetes 2004; 53: 608-15.

22 Tourrel C, Bailbe D, Meile MJ, Kergoat M, Portha B. Glucagon-like peptide-1 and exendin-4 stimulate beta-cell neogenesis in streptozotocin-treated newborn rats resulting in persistently improved glucose homeostasis at adult age. Diabetes 2001; 50: 1562-70.

23 George M, Ayuso E, Casellas A, Costa C, Devedjian JC, Bosch F. Beta cell expression of IGF-I leads to recovery from type 1 diabetes. J Clin Invest 2002; 109: 1153-63.

24 Hess D, Li L, Martin M, Sakano S, Hill D, Strutt B, et al. Bone marrowderived stem cells initiate pancreatic regeneration. Nat Biotechnol 2003; 21: 763-70.

25 Sutton R, Peters M, McShane P, Gray DW, Morris PJ. Isolation of rat pancreatic islets by ductal injection of collagenase. Transplantation 1986; 42: 689-91.

26 Abraham EJ, Leech CA, Lin JC, Zulewski H, Habener JF. Insulinotropic hormone glucagon-like peptide-1 differentiation of human pancreatic islet-derived progenitor cells into insulin-producing cells. Endocrinology 2002; 143: 3152-61.

27 Lumelsky N, Blondel O, Laeng P, Velasco I, Ravin R, McKay R. Differentiation of embryonic stem cells to insulin-secreting structures similar to pancreatic islets. Science 2001; 292: 1389-94.

28 Cozar-Castellano I, Weinstock M, Haught M, Velazquez-Garcia S, Sipula D, Stewart AF. Evaluation of beta-cell replication in mice transgenic for hepatocyte growth factor and placental lactogen: comprehensive characterization of the G1/S regulatory proteins reveals unique involvement of p21cip. Diabetes 2006; 55: 70-7.

29 Jonas JC, Sharma A, Hasenkamp W, Ilkova H, Patane G, Laybutt R, et al. Chronic hyperglycemia triggers loss of pancreatic beta cell differentiation in an animal model of diabetes. J Biol Chem 1999; 274: 14112-21.

30 Kojima H, Fujimiya M, Matsumura K, Younan P, Imaeda H, Maeda M, et al. NeuroD-betacellulin gene therapy induces islet neogenesis in the liver and reverses diabetes in mice. Nat Med 2003; 9: 596-603.

31 Kayali AG, Flores LE, Lopez AD, Kutlu B, Baetge E, Kitamura R, et al. Limited capacity of human adult islets expanded in vitro to redifferentiate into insulin-producing beta-cells. Diabetes 2007; 56: 703-8.

32 Baeyens L, De Breuck S, Lardon J, Mfopou JK, Rooman I, Bouwens L. In vitro generation of insulin-producing beta cells from adult exocrine pancreatic cells. Diabetologia 2005; 48: 49-57.

33 Davani B, Ikonomou L, Raaka BM, Geras-Raaka E, Morton RA, Marcus-Samuels B, et al. Human islet-derived precursor cells are mesenchymal stromal cells that differentiate and mature to hormoneexpressing cells in vivo. Stem Cells 2007; 25: 3215-22. 
34 Hardikar AA, Marcus-Samuels B, Geras-Raaka E, Raaka BM, Gershengorn MC. Human pancreatic precursor cells secrete FGF2 to stimulate clustering into hormone-expressing islet-like cell aggregates. Proc Natl Acad Sci USA 2003; 100: 7117-22.

35 Kimura K, Hattori S, Kabuyama Y, Shizawa Y, Takayanagi J, Nakamura $\mathrm{S}$, et al. Neurite outgrowth of PC12 cells is suppressed by wortmannin, a specific inhibitor of phosphatidylinositol 3-kinase. J Biol Chem 1994; 269: 18961-7.

36 Cao LZ, Tang DQ, Horb ME, Li SW, Yang $\sqcup$. High glucose is necessary for complete maturation of Pdx1-VP16-expressing hepatic cells into functional insulin-producing cells. Diabetes 2004; 53: 3168-78.

37 Giordano A, Galderisi U, Marino IR. From the laboratory bench to the patient's bedside: an update on clinical trials with mesenchymal stem cells. J Cell Physiol 2007; 211: 27-35.

38 lanus A, Holz GG, Theise ND, Hussain MA. In vivo derivation of glucose-competent pancreatic endocrine cells from bone marrow without evidence of cell fusion. J Clin Invest 2003; 111: 843-50.

39 Johansson U, Rasmusson I, Niclou SP, Forslund N, Gustavsson L, Nilsson B, Korsgren, O, Magnusson PU. Formation of composite endothelial cell-mesenchymal stem cell islets: a novel approach to promote islet revascularization. Diabetes 2008; 57: 2393-401.

40 Figliuzzi M, Cornolti R, Perico N, Rota C, Morigi M, Remuzzi G, Remuzzi A, Benigni A. Bone marrow-derived mesenchymal stem cells improve islet graft function in diabetic rats. Transplant Proc 2009; 41: $1797-$ 800. 